\title{
Impact of Different Cultivation Systems on Incidence of Natural Enemies in Rice Field
}

\author{
Y. Mounika*, C. Narendra Reddy, Y. Sridhar and D. Srinivasa Chary \\ Department of Entomology, College of Agriculture, Rajendranagar, \\ Hyderabad-500030, India \\ *Corresponding author
}

\section{A B S T R A C T}

\section{Keywords \\ Rice natural enemies, Incidence, Organic, \\ Biodynamic, Conventional cultivation \\ Article Info \\ Accepted: \\ 04 August 2019 \\ Available Online: \\ 10 September 2019}

The field experiment was conducted at College farm, College of Agriculture, Rajendranagar, Hyderabad during Rabi 2017-18 to evaluate the effect of different cultivation systems on incidence of spiders, coccinellids and per cent parasitisation in paddy with four treatments and three replications, taking TN1 as test cultivar and following the recommended package of practices under each cultivation systems. In general, there was no significant difference in the natural enemies' incidence between the systems but it was observed that comparatively higher population of spiders, coccinellids and per cent parasitisation were observed in biodynamic cultivation system followed by organic and conventional cultivation systems.

\section{Introduction}

Rice (Oryza sativa L.) is one of the important cereal crops of the world and forms the staple food for more than 65 per cent of the world population and known as king of cereals. Approximately 52 per cent of the global production of rice is lost annually owing to the damage caused by biotic stress factors, of which 21 per cent is attributed to the attack of insect pests (Yarasi et al., 2008). About 300 species of insects have been reported to attack rice crop in India, among the insect pests, yellow stem borer (Scirpophaga incertulas
WIk.), brown planthopper (Nilaparvata lugens Stal.), green leafhopper (Nephotettix spp.), ear head bug (Leptocorisa oratorius Fabricius), leaf folder (Cnaphalocrocis medinalis Gn.) and case worm (Nymphula depunctalis Guenee) are predominant. These pests infest the crop at all stages of plant growth and cause a variety of damage such as tissue boring, sap sucking, defoliation and leaf scrapping.

Though various management strategies are being adopted to check insect pests of rice, use of synthetic insecticides is a common method of pest control, which has increased rapidly 
and has over shadowed the traditional methods used to protect crop damage due to insects. Indiscriminate use of insecticides has resulted in undesirable side effects such as the development of resistance among insect pests, causing environmental pollution and health hazards to farmers (Hassal, 1990).

The effect of pesticides on non-target organisms has been a source of worldwide attention and concern for decades. Adverse effects of applied pesticides on non-target arthropods have been widely reported (Ware, 1980). Unfortunately, natural enemies e.g., parasitoids and predators are most susceptible to insecticides and are severely affected (Aveling, 1997, Vickerman, 1988). The destruction of natural enemies can exacerbate pest problems as they play an important role in regulating pest population levels.

Therefore, it has now become necessary to search for alternative means of pest control, which can minimize the use of synthetic pesticides. Maintenance of soil health without affecting the properties of soil (physical, chemical, biological etc.), sustainable crop production without harmful effects on environment. Information available on natural enemies of paddy insect pests from this area is meagre. An attempt has been made to study the natural enemy fauna associated with rice crop during Rabi 2017-2018.

\section{Materials and Methods}

The field experiments were laid out during summer 2017-18, in randomized block design (RBD) with four treatments and three replications at College farm, College of Agriculture, Rajendra Nagar to assess the incidence of spiders, coccinellids and per cent parasitisation under different rice cultivation systems such as organic cultivation, biodynamic cultivation, conventional cultivation systems. The soil of the experimental plot was light textured red sandy loam. TN1, a known insect pest susceptible cultivar was taken as the test cultivar. Planting was done in plots of size $20 \mathrm{~m} \times 5 \mathrm{~m}$ at spacing of $20 \mathrm{~cm} \times 10 \mathrm{~cm}$.

\section{Seed treatment}

The seeds were treated with Pseudomonas fluorescens $10 \mathrm{gm}$ per $\mathrm{kg}$ and soaked in 1 litre of water overnight under organic cultivation system.

In conventional cultivation system the seeds were treated with Bavistin (50 WP) @ 2g per litre of water for $1 \mathrm{~kg}$ seed, and dried for 30 minutes.

The seeds were treated with bheejamrutha and shade dried for 30 minutes under biodynamic cultivation system.

\section{Methods and time of application of manures and fertilizers}

During land preparation and puddling, 10 tonnes of FYM per ha and 5 tonnes of paddy straw per ha was incorporated in the soil. In the last puddle, 2 tonnes of vermicompost per ha was added under organic cultivation system.

NPK at 120:60:40 per ha respectively was applied under conventional cultivation system. Nitrogen was applied in the form of urea, phosphorus and potassium were applied in the form of single super phosphate and murate of potash respectively. Half of the nitrogen and total quantities of phosphorus and potassium were applied as basal dose prior to transplantation. The remaining half of the nitrogen was applied at panicle initiation stage.

In the last puddle ghanajeevamrutha at $10 \mathrm{~kg}$ per acre mixed with FYM was added to the 
field evenly and incorporated into the soil in biodynamic cultivation system.

\section{Plant protection}

Azardirachtin 1500 ppm @ 5ml per litre of water was sprayed at 25, 45 and 65 DAT.

Field release of Trichogramma chilonis @ $1,00,000$ per ha starting at 30, 45 and 60 DAT was undertaken in organic cultivation system.

Carbofuran 3G @ $1.0 \mathrm{~kg}$ a.i. per ha was applied at 25 DAT, Cartap hydrochloride 50 SP @ $300 \mathrm{~g}$ a.i. per ha was sprayed at 45 and 60 DAT under conventional cultivation system.

Spray application of jeevamrutha @ 200 litres per acre at 25 DAT, bhramasthra at 45 DAT, neemastra at 60 DAT and sour buttermilk at 80 DAT was undertaken under biodynamic cultivation system.

\section{Sampling techniques for record of spiders and coccinellids population}

Numbers of spiders per unit area were counted by searching the plants thoroughly. Spiders observed on the crop canopy, base and mid of the plants, from the webs in between the plants, from the webs in individual leaf folds, from water, border weeds and field bunds were carefully collected in specimen tubes and brought to the laboratory and sorted and grouped. For cocinellids the numbers of adult populations per unit area were counted in all the rice cultivation systems. The species identification of spiders and coccinellids was done at AICRP on Biological control of Crop Pests and Weeds, College of Agriculture, Rajendranagar, Hyderabad.

\section{Sampling technique for record of parasites}

The per cent parasitisation by Trichogramma, Tetrastichus and Telenomus sp was estimated through sentinel cards in all the test rice cultivation systems.

\section{Field release of sentinel cards}

Sentinel cards $(3 \times 4 \mathrm{~cm})$ with at least 100 inactivated and un-parasitized eggs of $C$. cephalonica were positioned on underside of the paddy leaves in all the four directions in all the test rice cultivation systems. The stapled cards were removed after 24 hrs of release and kept in glass vials. The recovered cards were maintained at ambient temperature of $27-30^{\circ} \mathrm{C}$ in AICRP on Biological control of insect pests and weeds laboratory, to record the percentage of parasitised eggs.

Per cent parasitisation $(\mathrm{egg})=$

Number of parasitoids emerged X 100

No. of parasitoids emerged + No. of larvae hatched.

The data thus obtained on incidence of spiders, coccinellids and parasite were computed. Data were subjected to ANOVA after suitable transformation and means were separated by Duncan's Multiple Range Test.

\section{Results and Discussion}

\section{Effect of different rice cultivation systems on incidence of spiders}

The spider populations were recorded from 40 DAT to maturity at ten days interval in different rice cultivation systems during rabi 2017-2018 is presented in Table 1. Spider population consisted of Pardosa pseudoannulata, Tetragnatha sp, Agelena sp, Oxyopes sp, Thomisus sp, and Araneus sp.

It was observed that spider population was found to increase gradually from 60 to 70 DAT and then decreased, with the advancement of crop growth. However, higher population was recorded in biodynamic cultivation (11.0 and 14.4 per $\mathrm{m}^{2}$ ) followed by 
organic cultivation (9.4 and 12.8 per $\mathrm{m}^{2}$ ) during 60 and 70 DAT respectively. In subsequent sampling dates i.e., 80, 90, 100, and 110 DAT spider population in different cultivation systems showed similar trends.

The present findings on the abundance of spiders are in agreement with Muthukrishnan et al., (1994) who reported that maximum number of spiders (5.7 per hill) were recorded in untreated control than in neem oil treated plots (4.0 per hill) and their number was still less in insecticide treated plots (1.7 per hill). Reddy, (2007) reported that the population of spiders was highest in organic plots with no plant protection. Karthikeyan et al., (2008) and Zhong et al., (2010) also reported that the spiders were higher in organic rice fields than conventional rice fields.

\section{Effect of different rice cultivation systems on incidence of coccinellids}

Coccinellid fauna in the experimental field consisted of Harmonia octomaculata Fabricius, Coccinella transversalis Fabricius, and Micraspis discolour. The data on coccinellid incidence in different rice cultivation systems during rabi 2017-2018 is presented in Table 2. Coccinellid population was found to increase gradually from 60 to 90 DAT and then decreased with the advancement of crop growth. However, the coccinellid population under different cultivation systems was found to follow almost similar trends to that of data registered at 50 DAT. The highest population was recorded in biodynamic cultivation (11.4 per $\mathrm{m}^{2}$ ) followed by organic cultivation (9.4 per $\mathrm{m}^{2}$ ) at 90 DAT.

Pfinner and Niggli (1996) reported that the activity as well density of carabids and spiders was high in the bio-dynamic and organic plots than in the conventional plots. Lawanprasert et al., (2006) reported that the highest population of coccinellids was observed in organic method as compared to conventional method of cultivation. Madhukar (2005) also reported that the population of lady bird beeteles, Micraspis discolour was more in rabi than kharif season. Incidence of insect pests was low in organically grown rice with high populations of natural enemies or predators was highest than conventional system as reported by Venkat et al., (2012).

\section{Effect of different rice cultivation systems on incidence of parasites}

Data revealed that there were no significant differences between the treatment means with respect to per cent parasitisation at all the sampling dates (Table 3). However, the total parasitisation varied from 6.9 per cent (organic cultivation) to 7.9 per cent (biodynamic cultivation) during second fortnight of March. During the second fortnight of March Telenomus was the predominant egg parasitoid followed by Trichogramma and low incidence of Tetrastichus was noticed.

During the first fortnight of April the total parasitisation varied from 7.5 per cent (conventional cultivation) to 9.9 per cent (biodynamic cultivation), with Trichogramma being the predominant egg parasitoid. Contrastingly, Telenomus parasitisation was more during first and second fortnight of April while Tetrastichus parasitization was negligible.

Borah et al., 2001; Srinivasan et al., 2001, also reported the safety of neem formulations to egg parasitoids. Manju and David (2004) reported that the parasitism was higher in neem cake treated plots and sprayed with neem products by 26.28 per cent than on NPK treated plots with no plant protection (20.92 per cent). 
Table.1 Effect of different cultivation systems on spider population at Rajendranagar during Rabi season 2017-18

\begin{tabular}{|l|c|l|l|l|l|l|l|l|l|}
\hline S.No & Treatment & \multicolumn{7}{|c|}{ Spider population per $\mathbf{m}^{2}$} \\
& & $\mathbf{4 0}$ DAT & 50 DAT & 60 DAT & 70 DAT & 80 DAT & 90 DAT & 100 DAT & 110 DAT \\
\hline $\mathbf{1}$ & Organic & $4.2^{\mathrm{b}}$ & $6.6^{\mathrm{b}}$ & $9.4^{\mathrm{ab}}$ & $12.8^{\mathrm{a}}$ & $11.6^{\mathrm{b}}$ & $10.2^{\mathrm{ab}}$ & $6.4^{\mathrm{b}}$ & $4.8^{\mathrm{a}}$ \\
& cultivation & $(2.10)$ & $(2.65)$ & $(3.14)$ & $(3.64)$ & $(3.45)$ & $(3.24)$ & $(2.62)$ & $(2.27)$ \\
\hline $\mathbf{2}$ & Biodynamic & $6.8^{\mathrm{a}}$ & $8.6^{\mathrm{a}}$ & $11.0^{\mathrm{a}}$ & $14.4^{\mathrm{a}}$ & $15.6^{\mathrm{a}}$ & $12.4^{\mathrm{a}}$ & $9.6^{\mathrm{a}}$ & $5.4^{\mathrm{a}}$ \\
& cultivation & $(2.69)$ & $(3.0)$ & $\left(3.3^{\mathrm{a}}\right)$ & $(3.85)$ & $(4.00)$ & $(3.59)$ & $(3.17)$ & $(2.42)$ \\
\hline $\mathbf{3}$ & Conventional & $6.4^{\mathrm{ab}}$ & $8.0^{\mathrm{ab}}$ & $9.0^{\mathrm{b}}$ & $11.0^{\mathrm{b}}$ & $10.8^{\mathrm{b}}$ & $10.0^{\mathrm{ab}}$ & $8.0^{\mathrm{ab}}$ & $5.4^{\mathrm{a}}$ \\
& cultivation & $(2.60)$ & $(2.90)$ & $(3.07)$ & $(3.38)$ & $(3.35)$ & $(3.23)$ & $(2.90)$ & $(2.42)$ \\
\hline $\mathbf{4}$ & Control & $4.8^{\mathrm{ab}}$ & $6.4^{\mathrm{b}}$ & $8.8^{\mathrm{b}}$ & $9.8^{\mathrm{b}}$ & $9.4^{\mathrm{b}}$ & $8.2^{\mathrm{b}}$ & $6.6^{\mathrm{b}}$ & $6.4^{\mathrm{a}}$ \\
& & $(2.29)$ & $(2.62)$ & $(3.04)$ & $(3.20)$ & $(3.14)$ & $(2.94)$ & $(2.65)$ & $(2.62)$ \\
\hline
\end{tabular}

*Figures in parenthesis are arc sine transformed values; Means followed by same alphabets in same column are significantly not different $(\mathrm{P}=0.05) \mathrm{LSD}$; DAT- days after transplanting.

Table.2 Effect of different cultivation systems on coccinellid population at Rajendranagar during Rabi season 2017-18

\begin{tabular}{|l|c|l|l|l|l|l|l|l|l|}
\hline S.No & Treatment & \multicolumn{8}{|c|}{ Coccinellid population per $\mathbf{m}^{2}$} \\
\hline & & $\mathbf{4 0}$ DAT & 50 DAT & 60 DAT & 70 DAT & 80 DAT 90 DAT & 100 DAT & 110 DAT \\
\hline $\mathbf{1}$ & Organic & $1.8^{\mathrm{a}}$ & $4.2^{\mathrm{a}}$ & $5.8^{\mathrm{b}}$ & $7.0^{\mathrm{b}}$ & $8.2^{\mathrm{b}}$ & $9.4^{\mathrm{a}}$ & $5.2^{\mathrm{a}}$ & $2.4^{\mathrm{a}}$ \\
& cultivation & $(1.44)$ & $(2.13)$ & $(2.49)$ & $(2.72)$ & $(2.94)$ & $(3.13)$ & $(2.37)$ & $(1.64)$ \\
\hline $\mathbf{2}$ & Biodynamic & $3.0^{\mathrm{a}}$ & $5.0^{\mathrm{a}}$ & $7.4^{\mathrm{a}}$ & $9.6^{\mathrm{a}}$ & $10.8^{\mathrm{a}}$ & $11.4^{\mathrm{a}}$ & $6.6^{\mathrm{a}}$ & $2.6^{\mathrm{a}}$ \\
& cultivation & $(1.17)$ & $(2.32)$ & $(2.80)$ & $(3.16)$ & $(3.35)$ & $(3.44)$ & $(2.66)$ & $(1.67)$ \\
\hline $\mathbf{3}$ & Conventional & $1.0^{\mathrm{a}}$ & $3.0^{\mathrm{c}}$ & $5.0^{\mathrm{bc}}$ & $6.8^{\mathrm{b}}$ & $8.8^{\mathrm{ab}}$ & $10.2^{\mathrm{a}}$ & $5.6^{\mathrm{a}}$ & $1.8^{\mathrm{a}}$ \\
& cultivation & $(1.16)$ & $(1.17)$ & $(2.33)$ & $(2.69)$ & $(3.04)$ & $(3.26)$ & $(2.45)$ & $(1.44)$ \\
\hline $\mathbf{4}$ & Control & $1.4^{\mathrm{a}}$ & $3.0^{\mathrm{bc}}$ & $3.8^{\mathrm{c}}$ & $4.2^{\mathrm{c}}$ & $6.0^{\mathrm{c}}$ & $6.4^{\mathrm{b}}$ & $5.4^{\mathrm{a}}$ & $3.4^{\mathrm{a}}$ \\
& & $(1.32)$ & $(1.85)$ & $(2.06)$ & $(2.16)$ & $(2.54)$ & $(2.62)$ & $(2.42)$ & $(1.92)$ \\
\hline
\end{tabular}

*Figures in parenthesis are arc sine transformed values; Means followed by same alphabets in same column are significantly not different $(\mathrm{P}=0.05) \mathrm{LSD}$; DAT- days after transplanting.

Table.3 Effect of different cultivation systems on per cent parasitisation at Rajendranagar during Rabi season 2017-18

\begin{tabular}{|r|c|c|c|c|c|}
\hline S.No & Treatment & \multicolumn{4}{|c|}{ Per cent parasitisation } \\
\cline { 3 - 6 } & & II FN March & I FN April & II FN April & I FN May \\
\hline \multirow{2}{*}{$\mathbf{1}$} & Organic cultivation & $6.9^{\mathrm{a}}$ & $8.3^{\mathrm{a}}$ & $9.5^{\mathrm{a}}$ & $9.5^{\mathrm{a}}$ \\
& & $(3.9)$ & $(4.2)$ & $(5.1)$ & $(5.0)$ \\
\hline \multirow{2}{*}{$\mathbf{2}$} & Biodynamic & $7.9^{\mathrm{a}}$ & $9.9^{\mathrm{a}}$ & $12.0^{\mathrm{a}}$ & $11.3^{\mathrm{a}}$ \\
& cultivation & $(4.4)$ & $(4.7)$ & $(6.5)$ & $(6.2)$ \\
\hline \multirow{2}{*}{$\mathbf{3}$} & Conventional & $7.0^{\mathrm{a}}$ & $7.5^{\mathrm{a}}$ & $9.3^{\mathrm{a}}$ & $9.6^{\mathrm{a}}$ \\
& cultivation & $(3.9)$ & $(3.9)$ & $(5.2)$ & $(5.9)$ \\
\hline \multirow{4}{*}{} & Control & $6.7^{\mathrm{a}}$ & $8.0^{\mathrm{a}}$ & $9.0^{\mathrm{a}}$ & $9.0^{\mathrm{a}}$ \\
& & $(3.4)$ & $(4.6)$ & $(5.5)$ & $(5.4)$ \\
\hline
\end{tabular}

*Figures in parenthesis are arc sine transformed values; Means followed by same alphabets in same column are significantly not different $(\mathrm{P}=0.05) \mathrm{LSD}$; DAT- days after transplanting. 
The factors responsible for the differences in natural levels of parasitisation and predator abundance in different systems of rice cultivation might lie in the spheres of fertilization, plant protection or their consequences such as weed flora, plant density or microclimate.

The population of natural enemies in conventional cultivation system was low probably due to toxic nature of chemicals. The negative effect of chemical insecticides on the population of natural enemies was reported by many workers (Dhaliwal and Arora, 2001; Nandarajan and Kumar, 2000).

Thus, from the results it can be concluded that the use of chemical pesticides causes significant reduction in the population of natural enemies of pests. This may reduce the efficiency of biological control of insect pest in rice field and can cause severe outbreak. Botanicals are less harmful and biodynamic preparations can be used in rice field for pest management without causing adverse effects on natural enemies and environment.

\section{References}

Aveling, C. 1997. The biology of Anthocorids (Heterophera: Anthocoridae) and their role in the integrated control of the damson-hop aphid (Phorodon humili schrank). PhD Thesis, University of London.

Borah, M., Basit, A and Nath, R.K. 2001. Effect of certain insecticides on the parasitisation and emergence of the egg parasitoid, Trichogramma japonicum Ashmead. Crop Research. 22(1): 138140.

Hassall, M.A. 1990. Biochemistry and use of pesticides. Macmillan press LTD, hound mills, Basingstoke, Hampshire and London, 536.

Karthikeyan, K., Sosamma, J.P and Smitha devi, S.M. 2008. Effect of botanicals against major insect pests and natural enemies in rice ecosystem. Journal of Biological Control. 22(2): 315-320.

Lawanprasert, A., Kunket, K., Arayarangasarit, L and Prasertsak, A. 2006. Comparison between conventional and organic paddy fields in Irrigated Rice Ecosystem. $4^{\text {th }}$ INWEPF Steering Meeting and Symposium, Bankok.

Madhukar, F.J. 2005. A preliminary study of the predatory natural enemy complex of rice ecosystem in Vidarbha region of Maharashtra, India. International Referred Research Journal. 2 (22): 2527.

Manju, S and David, P.M.M. 2004. Effects of soil and foliar applications of neem products on densities of rice yellow stem borer, Scirpophaga incertulas (Walker) egg masses and their parasitisim. Journal of Biological Control. 18(1): 41-44.

Muthukrishnan, N., Venugopal, M.S and Janathan, R. 1994. Evaluation of new insecticide formulations against rice leaf folder and stem borer. Pestology. 18(6): 12-14.

Pfinner, L and Niggli, U. 1996. Effects of bio-dynamic, organic and conventional farming on ground beetles and other epigaeic arthropods in winter wheat. Biological Agriculture and Horticulture.12: 353-364.

Reddy, D.B. 2007. Pests of food crops, Plant Protection in India. Allied Publication. Calcutta. 133-134.

Srinivasan, G., Babu, P.C.S and Murugeswari, V. 2001. Effect of neem products and insecticides on the egg parasitoids Trichogramma spp. (Trichogrammatidae: Hymenoptera). Pesticides Research Journal. 13: 250253.

Venkat Reddy, A., Sunitha Devi, R., Anitha, 
G and Vishnu Vardhan Reddy. 2012. Study on the incidence of insect pests and natural enemies as influenced by organic treatments in rice ecosystem. Journal of Research ANGRAU. 40(3): 9-13.

Vickerman, G.P. 1977. The effects of foliar fungicide on some insect pest of cereals. Pest and diseases. 2, 121-128

Ware, G.W. 1980. Effects of pesticides on nontarget organisms. Residue Reviews. 76: 173-201.

Yarasi, B., Sadumpati, V.; Immanni, C. P.;
Vudem, D. R. and Khareedu, V. R. 2008. Transgenic rice expressing Allium sativum leaf agglutinin (ASAL) exhibits high-level resistance against major sapsucking pests. Plant Biology, 8: 102115.

Zhong PingSheng., Wu, Y.Q and Zhong, Z.F. 2010. Dynamics investigation of major natural enemies in organic rice fields. Southwest China Journal of Agricultural Sciences. 23(4): 11071110.

\section{How to cite this article:}

Mounika, Y., C. Narendra Reddy, Y. Sridhar and Srinivasa Chary, D. 2019. Impact of Different Cultivation Systems on Incidence of Natural Enemies in Rice Field. Int.J.Curr.Microbiol.App.Sci. 8(09): 506-513. doi: https://doi.org/10.20546/ijcmas.2019.809.061 